\title{
Reserct Article: Effect of carrier and liquid biofertilizer on growth of mungbean using different method of application
}

\section{K. BHAVYA, R. SUBHASHREDDY, S. TRIVENI, K. DAMODHARA CHARI, G. THIRUMAL AND Y. NAGARAJU}

Article Chronicle:

Received :

17.07.2017;

Accepted :

01.08.2017]

KeY Words:

Rhizobium,

Phosphate

solubilizing bacteria,

Pot culture

experiment, Carrier

based biofertilizers,

Liquid based

biofertilizers

Author for correspondence :

\section{K. BHAVYA}

Department of

Agricultural

Microbiology and

Bioenergy, College of

Agriculture, Professor

Jayashankar Telangana

State Agricultural

University,

Rajendranagar,

HYDERABAD

(TELANGANA) INDIA

Email: bhavyaraj55@

gmail.com

See end of the article for

authors' affiliations
SUMMARY : In the present study different carrier and liquid biofertilizers are brought from different production centres. The field experiment was conducted following Complete Randomized Design with control and 12 treatments. The plant growth parameters viz., plant height, root length, nodule number per plant, nodule dry weight (g per plant), dry matter accumulation (g per plant), were observed at different crop growth stages.

How to cite this article : Bhavya, K., Subhashreddy, R., Triveni, S., Chari, K. Damodhara, Thirumal, G. and Nagaraju, Y. (2017). Effect of carrier and liquid biofertilizer on growth of mungbean using different method of application. Agric. Update, 12(TECHSEAR-6) : 1514-1519; DOI: 10.15740/HAS/AU/12.TECHSEAR(6)2017/ 1514-1519. 